\title{
Method of Defining the Parameters for UAV Point Cloud Classification Algorithm
}

\author{
Bui NGOC QUY ${ }^{1, *}$, Le DINH HIEN ${ }^{1,2)}$, Nguyen QUOC LONG ${ }^{1)}$, Tong SI SON ${ }^{3)}$, \\ Duong ANH QUAN ${ }^{1)}$, Pham VAN HIEP(1), Phan THANH HAI'), \\ Pham THI LAN ${ }^{1)}$
}

\footnotetext{
${ }^{1)}$ Hanoi University of Mining and Geology, Hanoi, Vietnam; email: buingocquy@humg.edu.vn; nguyenquoclong@humg.edu.vn; duonganhquan@humg.edu.vn; phamvanhiep@humg.edu.vn; phamthilan@humg.edu.vn

2) Natural resources and Environment one member co., ltd, Hanoi, Vietnam; email:

3) University of Science and Technology of Hanoi, Vietnam Academy of Science and Technology, Hanoi, Vietnam; email: hianry@gmail.com

4) Department of Cartography, General Staff of the Vietnam People's Army, Hanoi, Vietnam; email: phanhai0108@gmail.com
}

http://doi.org/10.29227/IM-2020-02-08

Submission date: 06-03-2020 | Review date: 22-09-2020

\section{Abstract}

Image data from Drones/Unmanned Aerial Vehicles (UAVs) has been studied and used extensively for establishing maps. The process of UAV data provides three main products including (Digital Surface Model) DSM, Point cloud and Ortho-photos, in which point cloud is a valuable data source in building $3 D$ models and topographic surfaces as well. However, processing point cloud separately to achieve secondary products has not been received much attention from researchers. This study determines parameters to develop a method for classifying point cloud data constructed from UAV images. Consequently, A 3D surface of the ground is built by applying a developed algorithm for the point cloud data for an open-pit mine. The temporal or non-ground objects such as trees, houses, vehicles are automatically subtracted from the point cloud by the algorithms. According to this line, it is possible to calculate and analyze the amount of reserves, the exploited volume to evaluate the efficiency for each mine during operation with the support of UAV integrated camera.

Keywords: UAV, point cloud, classification algorithms, open-pit mines

\section{Introduction}

The Unmanned Aerial Vehicles (UAV) image data processing through conventional software will provide products such as orthophotos, Digital Surface Model (DSM), and point clouds. Orthophotos are used to mapping topographic features, terrain objects, and DSM used to create Digital Elevation Models (DEM). In addition to the basic need of displaying the $3 \mathrm{D}$ view on a computer, point cloud data that interpolated from UAV has many applications such as 3D model, DSM, DEM creation, asset management, volume calculation. Application of UAV data in mapping has been studied and used by many scientists. With the advanced development of UAV technology in recent years, UAV has been applied in different mining activities including blast-induced ground vibration (Bui et al., 2020), mapping open-pit mines (Long et al., 2019; Bui et al., 2017; Nghia, 2020), stockpile computation (Canh, 2020), and pollution monitoring (Bui et al., 2019).

There have been many studies on point cloud data as well as point cloud classification algorithms proposed by many scientists in recent years (Lorenzo et al., 2018; Yumin et al., 2018; Ning et al., 2019; Geunsang et al., 2019; Mustafa et al. 2019; Jinbo et al., 2020). Han et al. (2017) have a detailed and complete overview of point cloud filtering algorithms. Zeng et al., (2016) filtered the point cloud by using the interpolation method combining Lagrange operator with local surface adjustment, which may not achieve the ideal filtering effect for point cloud data with unequal distribution due to the reason that the appropriate effect of the least square quadratic surface is not ideal (Zeng et al., 2016). Lin et al. (2017) proposed a distributed point cloud filter algorithm based on parametric adaptive anisotropic Gaussian kernel function. According to the local distribution characteristics of the point cloud, this algorithm can adaptively adjust the attenuation rate of each main direction of the filter and can effectively maintain the original sharp features of the point cloud model while eliminating the noise of scattered point clouds (Lin et al., 2017).

Among the commonly used noise reduction algorithms, the widely used bilateral filtering algorithm can achieve a better noise reduction effect (Yuan et al., 2015). However, the possibility of local errors substantially increases while handling the large-scale noise and unable to maintain the detailed features of the model point cloud. Li et al. proposed a noise reduction algorithm for point clouds based on noise classification (Li et al., 2016). Large-scale noise is removed by statistical filtering and radius filtering, and then small-scale noise is smoothed out by fast bilateral filtering, which can effectively maintain the geometrical features of the object being scanned. However, correlation statistics and radius parameters will have a serious effect on the filter because the farther away the values are from the centre of gravity of the pixels, the more they decrease. Wu et al., (2016) designed a filtering algorithm based on the average curvature feature classification, the traditional average, and the bilateral filtering algorithm applied to the respective feature areas (Wu et al., 2016).

Although there are many points filtering algorithms for Point cloud data, however, for the open pit area, the research 


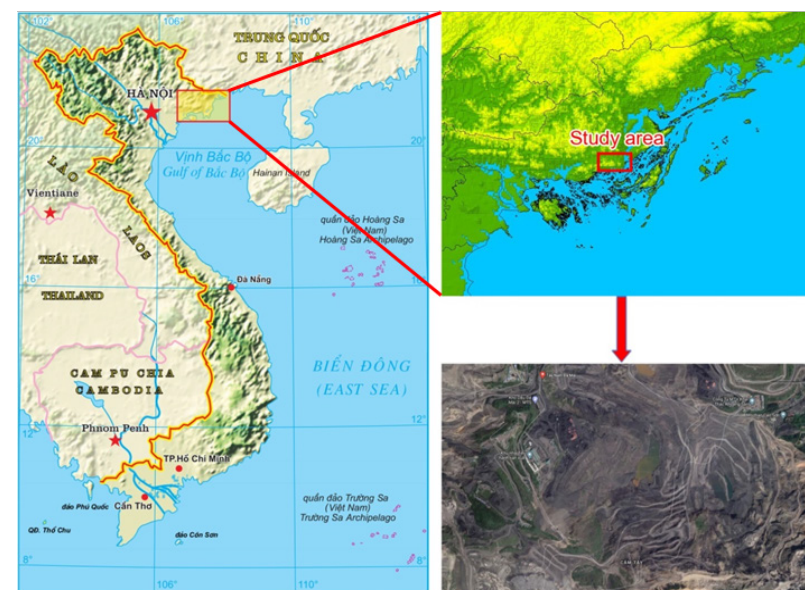

Fig. 1. Location of the study area Rys. 1. Położenie obszaru badań

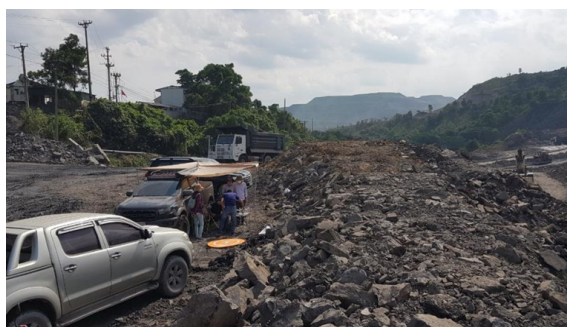

Fig. 2. Preparation of instruments for capture UAV images of the study area Rys. 2. Przygotowanie instrumentów do wykonywania zdjęć UAV badanego obszaru

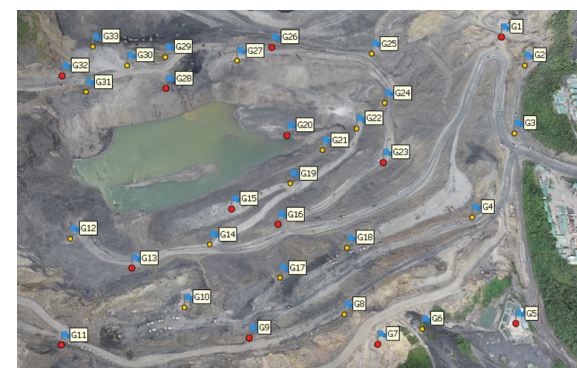

Fig. 3. Distribution of GCP of the studied area in the Dong Da Mai mine, Quang Ninh Rys. 3. Rozmieszczenie punktów kontrolnych badanego obszaru na terenie kopalni Dong Da Mai, Quang Ninh

on the Point cloud data classification algorithm from UAV images has not got attention. Therefore, in the scope of this paper, we focus on the determination of the parameters of Point cloud data classification from UAV images for the Dong Da Mai open-pit coal mines, Quang Ninh, Viet Nam.

\section{Study area}

Dong Da Mai open-pit coal mine $\left(107^{\circ} 17^{\prime} 28.64 " \mathrm{E}, 21^{\circ}\right.$ $2^{\prime} 15.10^{\prime N}$ ) is located in the frame of the Quang Ninh coal basin in northern Vietnam. This coal mine has been excavated for more than a century, and it is one of the biggest coal mines in Vietnam (Fig. 1). At the moment, the mine occupies a total area of 150 ha with proven reserves of 18 million tons and produces 1 million tons per year. Most of the mine is covered by a bare surface with rock and coal mineral. Some small areas on the top of the mine are covered by plantation forest and temporal houses for miners. The bottom of the mine is permanently flooded due to the rainwater and underground water (Fig. 3). During the exploitation, the mine modified and constituted a deep pit terrain at the elevation of $-100 \mathrm{~m}$ below sea level. Simultaneously, the soil dismantlement from the exploitation distributes wastes on the top of the pit mine at the elevation of $+30 \mathrm{~m}$ The highly different elevation between the top and the pit floor creates a steep slope the angle ranged from $10^{\circ}$ to $26^{\circ}$. Besides, the Dong Da Mai open-pit mine is in highly active exploitation day and night with dense mechanical equipment for transporting, loading, drilling, and blasting. Exploited activities along with the high risk from slope instability and the quick change of topography generate a dangerous environment for people working in the mine. Especially, this issue prevents the mangers from updating the topographic data using the traditional survey method with an optical instrument. Thus, using such an accurate, low cost and easy implementation as UAV photogrammetry technique is a promising solution to monitor the variation of the Dong Da Mai open-pit mine. 


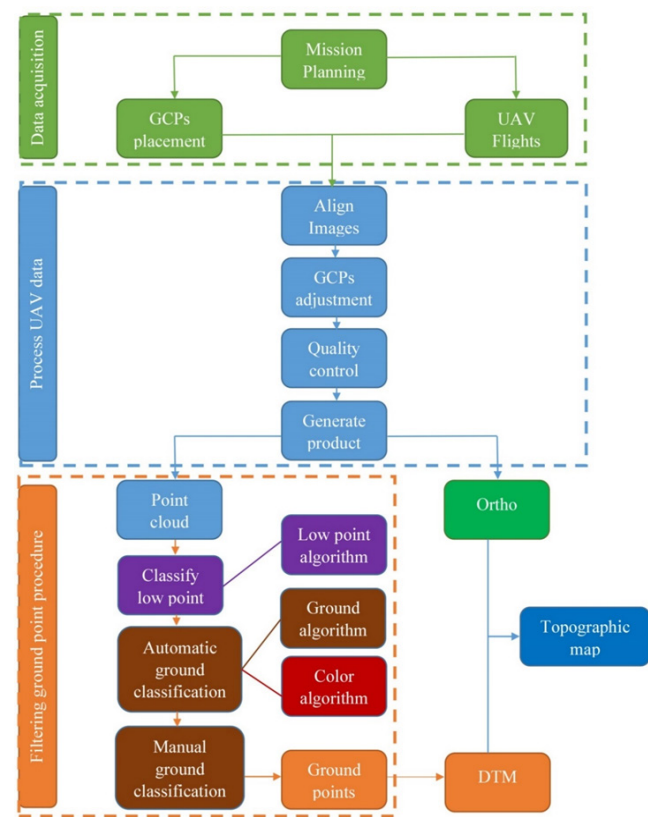

Fig. 4. Diagram of data processing process

Rys. 4. Schemat procesu przetwarzenia danych

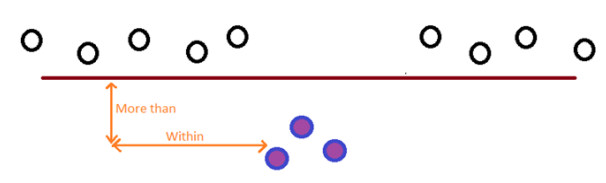

Fig. 5. The low point algorithm

Rys. 5. Algorytm punktu niskiego

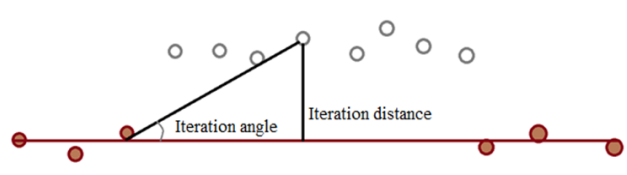

Fig. 6. The ground algorithm

Rys. 6. Algorytm naziemny

\section{Data and Methodology}

\subsection{Data in use}

The UAV photos used to generate cloud points are acquired by a common camera FC6310 integrated on a drone Phantom 4. The camera is equipped with a CMOS sensor with a size of $12.8333 \mathrm{~mm} \times 8.5556 \mathrm{~mm}$ and a focal length ranged from $8.8 \mathrm{~mm}$ to $24 \mathrm{~mm}$. The camera can take and store photos composing of three bands to produce natural color. UAV is designed to flight at the altitude $200 \mathrm{~m}$ from the take-off location of $30 \mathrm{~m}$ elevation to capture photos with an approximate $5.5 \mathrm{~cm}$ resolution. For the whole study area, 485 photos have been acquired on September 29th, 2019 at the Dong Da Mai open-pit coal mine area. The implement of UAV image acquisition is supported by experts of the University of Mining and Geology with the professional equipment seen in Figure 2.

Subsequently, a network of 33 Ground Control Points (GCPs) is appropriately distributed in the mine, in which 13 GCPs are used to orientate the point cloud and to optimize the camera positions as well (Fig 3). The 20 rest of GPSs is the referent data for accuracy assessment of DSM constructed from UAV photos. The GCP network is measured using the real-time kinetic (RTK) positioning technique and connecting to the national coordinate system.

\subsection{Research methodology}

UAV images were processed using GCPs to produce a precise ortho-photo and to interpolate point cloud. An automatically filtering procedure was applied to the point cloud in combination with manually editing to produce ground points for a Digital Terrain Model (DTM) generation (Fig 4).

\section{Ground point classification}

The automatically filtering out ground points consists of three algorithms: low point algorithm, ground algorithm, color algorithm.

\subsection{The filtering low point algorithm}

The low point algorithm allows filtering out single or group of points that are lower than others around points which might be error or noise points. Their height value will be collated with nearby points by two parameters that compute the $2 \mathrm{D}$ radius. The algorithm will classify points to low 


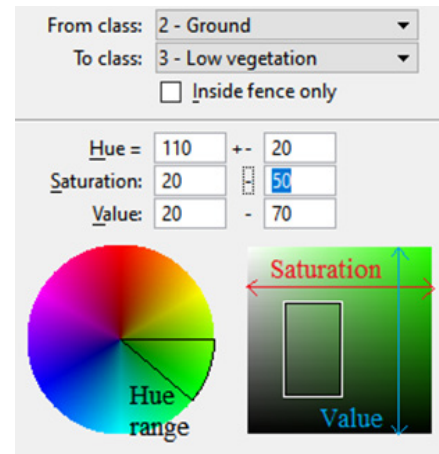

Fig 7. The color algorithm Rys. 7. Algorytm kolorów

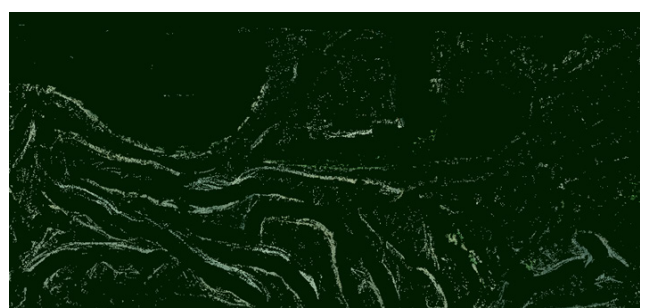

Fig. 8. Detected ground points after first ground routine in the Northside of the area (around our camp in figure 3) Rys. 8. Wykryte punkty naziemne po pierwszej procedurze naziemnej w północnej części obszaru (wokół naszego obozu na rysunku 3)

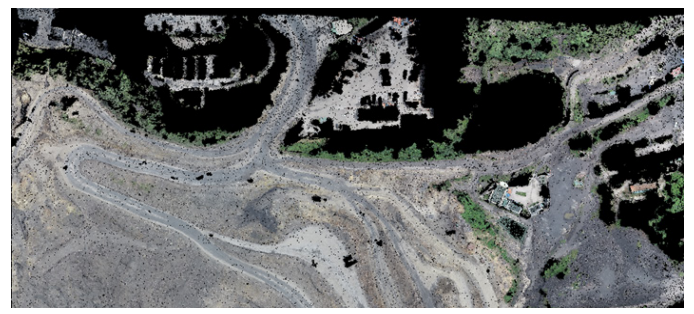

Fig. 9. Detected ground points after second ground routine in the Northside of the area (around our camp in figure 3)

Rys. 9. Wykryte punkty naziemne po drugiej procedurze naziemnej w północnej części obszaru (wokół naszego obozu na rysunku 3)

point class if their heights are lower than others following chosen parameters (Fig 5).

\subsection{The filtering ground algorithm}

The ground point algorithm is based on the method called progressive triangulated irregular network (TIN) densification. It automatically filters out ground points by continuously and repetitively generating TIN. The repetition begins with choosing the lowest point that might be a potential ground surface. This ground surface is determined by a max building size parameter which equals the longest edge of the biggest building. Afterwards, the algorithm will generate TIN surfaces from that initial point. The ground surface model becomes closer and closer to the real ground after each added point.

The algorithm uses an iteration angle and iteration distance parameters (Fig 6). The iteration angle is the widest angle between the line that represents the ground surface estimated by two outlying ground points and the line that connects the closest ground point to the searching point. Iteration distance is the range from the searching point projected to the ground surface. It helps to avoid picking points that are too high compared to ground. Those two parameters' values can be reduced automatically when the size of a triangle is reduced until its edge length is equal to a predefined value. Besides, edge length value can be used for the algorithm to stop triangulating. Moreover, terrain angle can be used to define the biggest allowed terrain steep angle. This parameter is normally set 10-15 degrees higher than the steepest angle in the process area.

\section{3 The color filtering algorithm}

The color algorithm is based on the color value of each point. Since the point cloud data is interpolated from UAV images, every point has color following captured images. The color value is defined by HSV (Hue - Saturation - Value) (Fig 7). Therein, Hue is the color value divided by a $360^{\circ}$ circle including Red to Yellow; $0^{\circ}$ to $60^{\circ}$, Yellow to Green; $60^{\circ}$ to $120^{\circ}$, Green to Cyan; $120^{\circ}$ to $180^{\circ}$, Cyan to Blue; $180^{\circ}$ to $240^{\circ}$, Blue to Purple; $240^{\circ}$ to $300^{\circ}$, Purple to Red; $300^{\circ}$ to $360^{\circ}$.

Saturation is the purity of the color of each point. The closer the color to a gray shade is, the lower the saturation value is. Value is the brightness of the color ranged from 0 to 255 varying from black to white, respectively. The algorithm automatically classifies every point that has its color value falling inside a predefined HSV range into a wanted point class. 

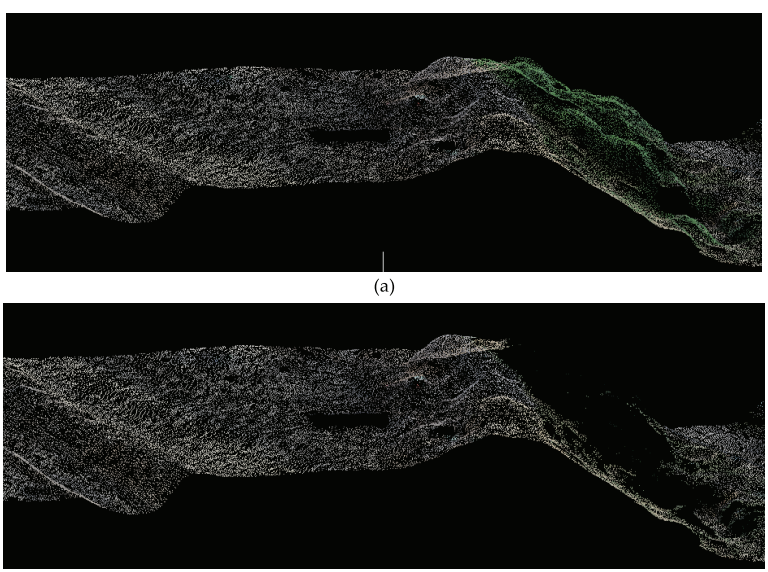

(b)
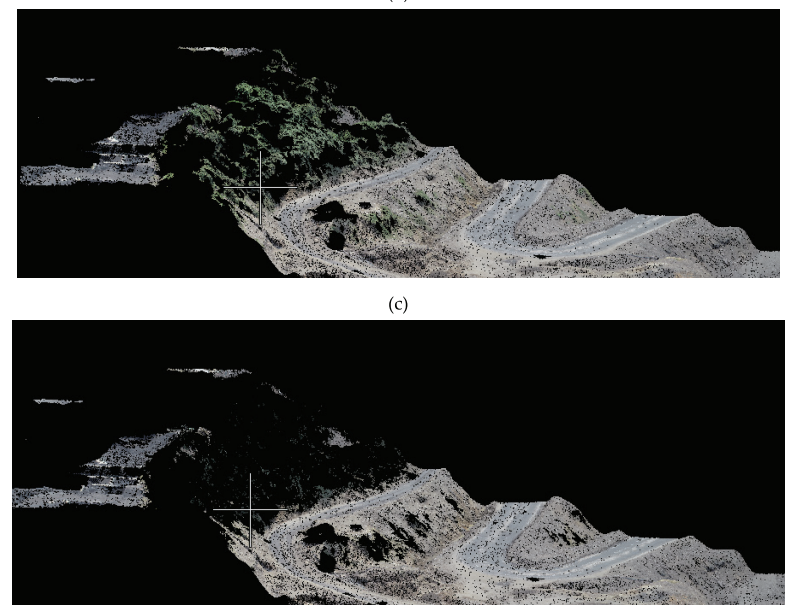

(d)

Fig. 10. Ground points before $(a ; c)$ and after the color algorithm (b; d) Rys. 10. Punkty naziemne przed (a; c) i po algorytmie koloru (b; d)

\section{Results and Discussions}

\subsection{Algorithm developed for filtering non-ground objects}

Firstly, the low point algorithm is executed.

To avoid the removal of too many points that might be actual ground points, the algorithm proceeds three times, and each time maximum points and radius parameters are decreased.

$1 /$ searching for a maximum 30 points lower than nearby points more than $0.5 \mathrm{~m}$ inside a $5 \mathrm{~m}$ radius

$2 /$ searching for a maximum 5 points lower than nearby points from 0.3 to $0.5 \mathrm{~m}$ inside a $3 \mathrm{~m}$ radius

3 / searching for 1 point lower than nearby points from 0.2 to $0.3 \mathrm{~m}$ inside a $2 \mathrm{~m}$ radius.

Secondly, the ground algorithm is executed twice times. The point cloud is proceeded to detect certain confident initial ground points. The reducing iteration angle with edge length and stop iteration corresponding to the edge length parameters are used. Detailed parameters are as following:

Max building size: $40 \mathrm{~m}$

Terrain angle: $88^{\circ}$

Iteration angle: 8

Iteration distance: $1 \mathrm{~m}$

Reduce Iteration angle when edge length is lower than $10 \mathrm{~m}$

Stop iteration when edge length is lower $5 \mathrm{~m}$
Detected ground points after the first ground routine are depicted in Figure 8 and Detected ground points after second ground routine are depicted in Figure 9.

Since the UAV point cloud is dense distribution, the second implementation of the ground algorithm is compulsory to detect all the ground points without the stop iteration with edge length parameter and with a lower iteration angle and shorter iteration distance. Detailed parameters are as following:

- Using the classified ground points as current ground.

- Terrain angle: $88^{\circ}$

- Iteration angle: 5

- Iteration distance: $0,4 \mathrm{~m}$

- Reduce Iteration angle when edge length is lower than $3 \mathrm{~m}$

- Stop iteration when edge length is unused.

Recognizing that few vegetation areas that have similar shapes with terrain are incorrectly classified as ground; therefore, a color algorithm is needed to filter out those wrong points. After collecting a few color samples from those wrong points and running a few testing times, an optimized color parameter from Green band to Cyan is selected to reject false ground points from vegetation and water.

- Hue from $90 \div 130$

- Saturation from $5 \div 100$

- Value from $5 \div 100$. 


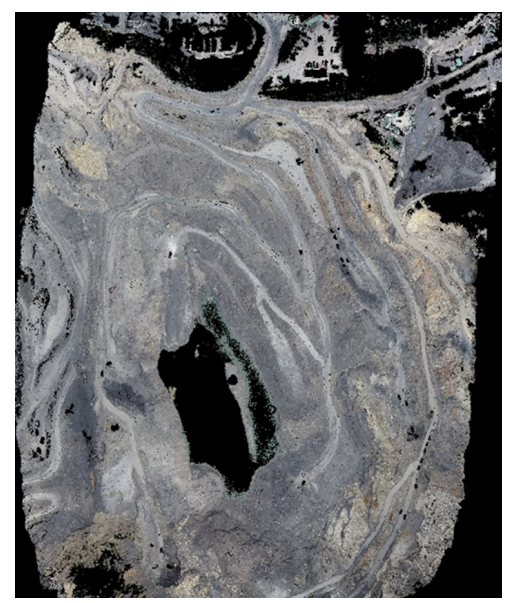

Fig. 11. Ground points after the algorithm Rys. 11. Punkty naziemne po algorytmie

Tab. 1. Result assessment of the automatic ground classification

Tab. 1. Ocena wyników automatycznej klasyfikacji gruntu

\begin{tabular}{|c|c|c|c|c|c|}
\hline & $\begin{array}{c}\text { The actual building } \\
\text { area was classified } \\
\text { into ground }\end{array}$ & $\begin{array}{c}\text { Actual vegetation } \\
\text { area was classified } \\
\text { into ground }\end{array}$ & $\begin{array}{c}\text { Another area } \\
\text { was classified } \\
\text { into ground }\end{array}$ & $\begin{array}{c}\text { The ground area } \\
\text { was not classified }\end{array}$ & $\begin{array}{c}\text { The total wrong classified } \\
\text { ground area }\end{array}$ \\
\hline Areas (m2) & 329.73 & 2143.245 & 1978.38 & 88532.5 & 101227.11 \\
\hline Ratio & $0.04 \%$ & $0.26 \%$ & $0.24 \%$ & $10.74 \%$ & $12.28 \%$ \\
\hline
\end{tabular}

Finally, we get the filter result as shown in Figure 10: Ground points before $(\mathrm{a} ; \mathrm{c})$ and after the color algorithm $(\mathrm{b} ; \mathrm{d})$

\subsection{Accuracy assessment of the ground point model}

Figure 11 illustrates the DTM after the application of thee algorithms. The color in the figure is the color of the point cloud generated from UAV photos. The black area is the location of filtered trees, houses, and water surfaces. Black regions with the random shape of are dense trees distribute on the top and surrounding area the mine. Some scattered black rectangles next to the trees are primitive locations of houses on ortho-images. Besides, some small black rectangles forms in dash lines along with the benches, are trucks for transportations. A huge area in the mid of Figure 11 refers to the water surface. The ground points generated in the study are valuable data to construct DTM using the interpolation method.

Table 1 shows the statistic number of total area: 824325 $\mathrm{m}^{2}$ and the accuracy of the automatic ground classification: $87.72 \%$. The algorithm is effective in filtering out vehicles, sparse vegetation. Most buildings are filtered out, but few tents were inaccurately classified into the ground because they have the same figure with the terrain. Since the number of buildings in the study area is small, the error from buildings is low: $0.04 \%$. The error from the vegetation area is also low because of the color algorithm. However, inside dense vegetation area, no ground point was interpolated; thus, those areas caused the highest error: $10.74 \%$. The majority part of $0.24 \%$ other area was classified into the ground is water area.

Table 2 indicates the root mean square error (RMSE) of DTM constructed using point cloud after applying algorithms. The errors are based on the comparison between coordinates of 20 checking points and the corresponding coordinates of that points extracted on the DTM in three dimensions X, Y, $\mathrm{Z}$. The lowest accuracy is seen at the point G2 with $19.0 \mathrm{~cm}$ of
XYZ error, but the best one is at the point G19 with only 1.7 $\mathrm{cm}$ of errors. The almost ten times difference between the two critical points can be explained by the distribution of GCPs surrounding the checking points (Fig 2). The G19 point is located in the centre of 4 GCPs (G15, G16, G20, G23) with the relatively even different distances that improve the accuracy of the constructed DTM. Contrastingly, the G2 location is outside the closest triangle fixed by three GCPs G1, G5, and G23, the lack of GCPs in the area of G2, G3 increases the error of DTM. The similar issue of DTM at G2 is seen at G3 with the XYZ error reaching to $15 \mathrm{~cm}$. According to the rule that the even distribution of GCPs increases the accuracy of the point cloud, the coordinates of checking points G3, G4, G18 should be used for the orientation and adjustment of the point cloud. Overall, the DTM is generated with the RSM error of $8.4 \mathrm{~cm}$. The vertical accuracy $(8.4 \mathrm{~cm})$ of the DTM is, as usual, lower than the horizontal accuracy with $2.6 \mathrm{~cm}$ of X RMSE and $3.5 \mathrm{~cm}$ of Y RMSE, respectively. The constructed DTM is possibly met the accuracy requirement for updating the topography and estimating the productivity of the mine in this study.

\section{Conclusions}

UAV photogrammetry is an idea for surveying in such an environment as open-pit mine since it meets the requirement of quickly monitoring the variation of topography with low cost and high accuracy. However, the common technique to process UAV photos generates DSM instead of DTM. The automatic subtraction of temporal objects as houses, trees from DSM is always the challenger to achieve a DTM. This study develops an automatic ground filtering procedure in a combination of three different algorithms: low point algorithm, ground algorithm, and color algorithm. The result is promising with $87.72 \%$ accuracy; almost non-ground objects were 
Tab. 2. The accuracy of DTM constructed from UAV images

Tab 2. Dokładność NMT zbudowanego z obrazów BST

\begin{tabular}{|c|c|c|c|c|c|}
\hline Label & X error (cm) & Y error (cm) & Z error (cm) & $\begin{array}{c}\text { XYZ error } \\
\text { (cm) }\end{array}$ & Image (pix) \\
\hline G3 & 1.1 & 8.0 & 13.7 & 15.9 & $0.364(22)$ \\
\hline G2 & 0.4 & 6.8 & 17.8 & 19.0 & $0.384(21)$ \\
\hline G18 & -1.0 & 1.0 & 9.0 & 9.1 & $0.491(59)$ \\
\hline G17 & 0.2 & 1.5 & 9.6 & 9.8 & $0.354(44)$ \\
\hline G10 & -0.1 & 1.2 & 11.2 & 11.3 & $0.393(47)$ \\
\hline G4 & -1.0 & 5.5 & 1.7 & 5.8 & $0.444(42)$ \\
\hline G8 & -0.4 & 1.0 & 8.1 & 8.2 & $0.473(42)$ \\
\hline G6 & 5.6 & 2.3 & -6.8 & 9.1 & $0.384(31)$ \\
\hline G33 & -1.2 & -0.5 & -11.9 & 12.0 & $0.366(40)$ \\
\hline G30 & -2.4 & 1.7 & 2.4 & 3.8 & $0.318(55)$ \\
\hline G31 & -0.4 & -0.4 & 3.5 & 3.5 & $0.330(48)$ \\
\hline G29 & 0.5 & 2.9 & -1.4 & 3.3 & $0.404(61)$ \\
\hline G27 & 4.2 & 1.3 & 6.5 & 7.9 & $0.356(65)$ \\
\hline G25 & 7.0 & -1.7 & 4.6 & 8.6 & $0.378(58)$ \\
\hline G24 & 2.0 & -4.6 & 8.0 & 9.5 & $0.420(65)$ \\
\hline G14 & -1.9 & -0.6 & 0.8 & 2.2 & $0.391(77)$ \\
\hline G19 & -1.3 & -0.1 & 1.1 & 1.7 & $0.425(87)$ \\
\hline G22 & 0.0 & -4.4 & -2.3 & 4.9 & $0.432(90)$ \\
\hline G21 & -1.4 & -5.2 & -10.8 & 12.0 & $0.471(93)$ \\
\hline G12 & -4.0 & -1.9 & -8.1 & 9.2 & $0.395(66)$ \\
\hline RMSE & $\mathbf{2 . 6}$ & $\mathbf{3 . 5}$ & $\mathbf{8 . 4}$ & $\mathbf{9 . 4}$ & $\mathbf{0 . 4 0 7}$ \\
\hline
\end{tabular}

filtered out. Although a few manual works left are required to generate the DTM, the method developed in this study can be popularly used for other study areas.

\section{Acknowledgements}

This work was financially supported by the Ministry of Education and Training (MOET) in Viet Nam under grant number B2020-MDA-14.

\section{Literatura - References}

1. Bui, X.N., et al., Use of Unmanned Aerial Vehicles for 3D topographic Mapping and Monitoring the Air Quality of Open-pit Mines. Inżynieria Mineralna, 2019. 21.

2. Canh, L.V., Cuong, C.X., Viet, L.H., Tien, Dinh., (2020). Volume computation of quarries in Vietnam based on Unmanned Aerial Vehicle (UAV) data. Mining and earth sciences, 61(1), 21-30. doi:10.46326/JMES.2020.61(1).03

3. Geunsang Lee, Mikyoung Choi, Wansik Yu, Kwansue Jung, (2019). Creation of river terrain data using region growing method based on point cloud data from UAV photography, Quaternary International, Volume 519, Pages 255-262.

4. Han X. F., Jin J. S., Wang M. J., et al. (2017). A review of algorithms for filtering the 3D point cloud. Signal Processing Image Communication, Volume 57:103-112.

5. Jinbo Lu, Hong Wang, Shuhong Qin, Lin Cao, Ruiliang Pu, Guilin Li, Jing Sun, (2020). Estimation of aboveground biomass of Robinia pseudoacacia forest in the Yellow River Delta based on UAV and Backpack LiDAR point clouds, International Journal of Applied Earth Observation and Geoinformation, Volume 86, 102014.

6. Lin H. B., Fu D. M., Wang Y. T. (2017). Feature preserving denoising of scattered point cloud based on parametric adaptive and anisotropic gaussian kernel. Computer Integrated Manufacturing Systems, Volume 23(12):2583-2592.

7. Li P. F., Wu H. E., Jing J. F., et al., (2016). Noise classification denoising algorithm for point cloud model. Computer Engineering and Application, Volume 52(20):188-192.

8. Long, N. Q., Nam, B. X., Cuong, C. X., \& Canh, L. V. (2019). An approach of mapping quarries in Vietnam using low-cost Unmanned Aerial Vehicles. International Journal of Sustainable Development, 11(2):199-210. doi:10.21177/1998-4502-2019-11-2-199-210. 
9. Lorenzo Comba, Alessandro Biglia, Davide Ricaud Aimonino, Paolo Gay, (2018). Unsupervised detection of vineyards by $3 \mathrm{D}$ point-cloud UAV photogrammetry for precision agriculture, Computers and Electronics in Agriculture, Volume 155, Pages 84-95.

10. Mustafa Zeybek, İsmail Şanlığlu, (2019). Point cloud filtering on UAV based point cloud, Measurement, Volume 133, Pages 99-111.

11. Ning Ye, Louise van Leeuwen, Panagiotis Nyktas, (2019). Analysing the potential of UAV point cloud as input in quantitative structure modelling for assessment of woody biomass of single trees, International Journal of Applied Earth Observation and Geoinformation, Volume 81, Pages 47-57.

12. Nghia, N. V. (2020). "Building DEM for deep open-pit coal mines using DJI Inspire 2. Journal of Mining and Earth Sciences, 61(1), 1-10. doi:10.46326/JMES.2020.61(1).01.

13. Wu L. S., Shi H. L., Chen H. W., (2016). Denoising of three-dimensional point data based on classification of feature information. Optics and Precision Engineering. Volume 24(6):1465-1473.

14. Yuan H., Pang J. P., Mo J. W., (2015). Denoising algorithm for bilateral filter point based on noise classification. Journal of Computer Applications, Volume 35(8):2305-2310.

15. Zeng F. X., Li L.,(2016). Research on point cloud filtering based on Lagrange operator and surface fitting. Journal of laser, Volume 37(8):75-78.

16. Yumin Tan, Shuai Wang, Bo Xu, Jiabin Zhang, (2018). An improved progressive morphological filter for UAV-based photogrammetric point clouds in river bank monitoring, ISPRS Journal of Photogrammetry and Remote Sensing, Volume 146, Pages 421-429.

\section{Method of defining the parameters for UAV point cloud classification algorithm}

Dane uzyskane $z$ dronów / bezzałogowych statków powietrznych (BSP) zostały zbadane i powrzechnie wykorzystane do opracowania map. Przetwarzenie danych z BSP zapewnia trzy główne produkty, amianowicie: Model numeryczny powierzchni (MNS), chmurę punktów i ortofotomapy, w których chmura punktów jest cennym źródłem danych przy budowaniu modeli 3D i powierzchni topograficznych. Dotychczas, kwestia przetwarzania chmury punktów osobno w celu uzyskania produktów wtórnych nie wzbudziła większego zainteresowania naukowców. W artykule, przedstawiono wyniki badania nad sposobem wyznaczenia parametrów niezbędnych do opracowania metod klasyfikacji danych chmur punktów zbudowanych z obrazów BSP. W efekcie tego procesu, powstaje trójwymiarowa powierzchnia powierzchni poprzez zastosowanie opracowanego algorytmu dla danych chmury punktów w kopalni odkrywkowej. Na tej podstawie, można służyć do pomiarów inwentaryzacyjnych, bieżacej kontroli zgodności postępu eksploatacji górniczej z planem ruchu zakładu górniczego, prowadzenia pomiarów postępu frontu eksploatacji w złożu oraz frontów, obejmujacych proces zdejmowania nadkładu oraz wyeksploatowanego złoża.

Słowa kluczowe: BSP, chmura punktów, algorytmy klasyfikacyjne, kopalnie odkrywkowe 